\title{
A new mysid (Crustacea, Mysida) from the Ladinian Stage (Middle Triassic) of Conca de Barberà (Catalonia, NE Iberian Peninsula)
}

\author{
Carlos San Vicente ${ }^{1}$ and Joan Cartanyà ${ }^{2,3}$ \\ ${ }^{1}$ c/Nou núm. 8. 43839 Creixell-Tarragona, Spain 〈csanvicente@gencat.cat〉 \\ ${ }^{2}$ Institut Català de Paleontologia Miquel Crusafont c/ Escola Industrial, 23 - 08201 Sabadell, Spain 〈joan.cartanya@icp.cat〉 \\ ${ }^{3}$ Centre d'Història Natural de la Conca de Barberà, c/ Pedrera, 2 - 43400 Montblanc, Spain
}

\begin{abstract}
The oldest known fossil mysid (order Mysida) Aviamysis pinetellensis n. gen. n. sp. is described here from two nearly complete specimens found in the Alcover unit from El Pinetell (Catalonia). It differs significantly from other Mysida and is placed in a new genus assigned to the family Mysidae and tentatively to the subfamily Boreomysinae. These specimens represent the first described mysid material from the Alcover outcrops (Middle Triassic, upper Ladinian, 235-242 Ma), extending the known geological range of the poorly understood fossil fauna of the order Mysida by at least 70 Myr.
\end{abstract}

\section{Introduction}

The Middle Triassic was an exceptional time period during which, after the end-Permian mass extinction, several global factors determined an acceleration in the recovery and extensive radiation of biota (Erwin, 1996). This key process in the evolution of life ended with the replacement of the "Palaeozoic Fauna" with the "Modern Fauna" (Sepkopski, 1984; MárquezAliaga, 2010; Escudero-Mozo et al., 2015). Between recognized biotic elements of the Middle Triassic, "mysidaceans" were one of the dominant components with a probably high abundance in some geographical areas (Feldmann et al., 2015, 2017).

The orders Mysida, Stygiomysida, and Lophogastrida, earlier referred to as the "Mysidacea," consist of 1200 described species and 187 genera found at the present across all latitudes throughout the waters of the world, with the majority of species inhabiting coastal and open-ocean waters (Meland et al., 2015). The "Mysidacea" refers to a paraphyletic group of the aforementioned taxa, including also the members of the extinct Carboniferous/Permian order Pygocephalomorpha, all considered as relatively primitive carapaced peracarids (Taylor et al., 2001).

During the Carboniferous, two lineages of the "Mysidacea," the Pygocephalomorpha and the Lophogastrida, first appeared in the fossil record (Schram, 1986; Taylor et al., 2001). The order Pygocephalomorpha are among the most common of eumalacostracan crustaceans preserved in the near-shore and brackish-water communities of the late Paleozoic (Schram, 1986). Pygocephalomorpha might be related to recent Mysida or, more likely, recent Lophogastrida, but there has been much disagreement as to the relationships among these three orders (Schram, 1986; Taylor et al., 1998). The order Lophogastrida is represented in the fossil record from the Carboniferous to the
Jurassic with an apparent long persistence of body form, a trend already noted in other living members of the order Mysida (Taylor et al., 2001). No fossils are known in the order Stygiomysida, but the actual distribution of this family follows the path of the former Tethyan Sea (Pesce and Iliffe, 2002), which extended during the Mesozoic from today's Caribbean eastwards to the Indian Ocean (Meland et al., 2015).

As opposed to the fossil records of Lophogastrida and the species-rich fossil order Pygocephalomorpha, few fossil Mysida have been identified to date. Since the known Mysida have a soft body, it is assumed that they are generally poorly predisposed for fossilization and, consequently, their fossil record depends on exceptional conditions of conservation and fossilization (Secretan and Riou, 1986).

The earliest fossils attributed to the Mysida were the species Elder ungulatus Münster, 1839, and Francocaris grimmi Broili, 1917, both from the Jurassic Solnhofen limestones of Bavaria (Germany). However, Schram (1986, p. 124) and Taylor et al. (2001, p. 310) did not agree with this attribution. Indeed, they said that these taxa are "too poorly understood to permit an unqualified assignment."

The oldest "true" mysida fossils have been dated as far back as the Middle Jurassic (Callovian, 163-166 Myr) from the deposits of la Voulte-sur-Rhône, Ardeche, France. In that fossil site, Secretan and Riou (1986) described Siriella antiqua and $S$. carinata, both with amazing similarity to extant forms.

The partial reconstruction of specimen LH 343 initially attributed to the family Eryonidae (order Decapoda) by Sanz et al. (1988) from the Lower Cretaceous of las Hoyas fossil site (Cuenca, Spain) led Rabadà (1990) to include it in the Mysida, but the lack of more and better specimens leaves its affiliation doubtful. With a habitus apparently similar to fossils described by Rabadà (1990), De Angeli and Rossi (2006) described 
Mysidopsis oligocenicus from the lower Oligocene of NE Italy, although its generic status is not clear due to a suboptimal state of preservation (Wittmann et al., 2014). In addition, fossil mysid statoliths have been described in Miocene deposits of the brackish Paratethys (Voicu, 1974, 1981; Ionesi and Pascariu, 2011) and in the Aquitanian basin (SW France) (Steurbaut, 1989).

Cartanyà (1991) first described a crustacean found in the Triassic reservoir of the Pinetell (Montblanc, Spain) and identified it with certain reservations as a "mysidacean." In this paper, a black and white photograph and a drawing with the trace of uropodal endopod statocysts are presented. A second "mysidacean" specimen was reported by Cartanyà (1999b) without any reference to its morphology. Revision of the aforementioned fossil specimens allows us to re-describe in detail their morphological characteristics and ascribe them to a new genus and new species of the order Mysida.

This paper presents the results of this review as well as a discussion of the position of the new taxon between the different mysid families and subfamilies. The discovery of the fossil specimens from the Pinetell presented in this study extends the range of Mysida by 70 Myr.

\section{Stratigraphic and environmental settings}

Marine conditions present in the Iberian region during the Triassic, especially during the late Anisian and the entire Ladinian, include a wide diversity of coastal and marine depositional environments (shores, lagoons, tidal flats, reefs, etc.) (López-Gómez et al., 2002).

The Prades Mountains are located in the middle of the Catalonian Prelitoral Range, part of the Catalonian Coastal Ranges, and make up one of the most important physiographic units in the NE of the Iberian Peninsula. This unit is structured by a Paleozoic basement and a Mesozoic cover, which is composed for the most part of Triassic sediments (Cartanyà, 1999b). The main features of the European lithostratigraphic unit upper Muschelkalk in the eastern Prades Mountains are the presence of mound-reefs and of laminated dolomites in the Alcover unit filling the interreef depressions (Calvet and Tucker, 1995; Tucker and Marshall, 2004). The Alcover laminated dolomites unit is up to $70-80 \mathrm{~m}$ thick, and fills the inter-reef depressions with a sharp, undulating, and locally erosive unconformity. Stratigraphically it is dated as late Ladinian (middle Triassic) (Calvet et al., 1987; Calvet and Tucker, 1995), upper Muschelkalk, from 235-242 Myr (Lucas, 2010).

According to Esteban et al. (1977), the Alcover unit is composed of a clearly marine laminated dolomicrite. The uniformity of the lamination, its fine grain size, the absence of structures such as ripples, and presence of euhedral halite crystals, suggest a very calm and hypersaline depositional environment. Also, these authors suggested the following depositional sequence: (1) the Alcover unit was deposited in an anoxic basin, affected by sporadic currents (of density?) and evolving to hypersaline conditions; (2) it settled among preexisting depressions due to former bioherms; (3) the deposit was caused by decanting from muddy suspensions.

The Alcover unit has yielded an abundant Triassic fauna, traditionally considered as originating in a shallow, lagoonal basin within an extended reef complex (Fortuny et al., 2011).
The fossil assemblage is allochtonous and composed of floral and faunal groups such as land plants, jellyfishes, brachiopods, molluscs, arthropods, echinoderms, fishes, and reptiles (Villalta and Via, 1966; Via and Villalta, 1975; Beltan et al., 1989; Carrasco, 2012), but the reputation of these localities is based on the fossils being preserved in dolomicrite and their ichthyofaunal diversity (Cartanyà, 1999a, 1999b).

Via et al. (1977) suggested a general parallel between sedimentological and paleobiological conditions of the Alcover unit and the well-known conditions of the Solnhofen-type limestones, based on several observations: the available paleontological collections show a clear predominance (79.6\%) of nectonic organisms (e.g., fishes, reptiles, cephalopods, swimming decapods), and benthic organisms well represented by limulids, decapods, holothurians, crinoids, and brachiopods. In addition, there is a remarkable assemblage of semiterrestrial reptiles, insects, and several terrestrial plants. Algae, sponges, corals, bryozoans, gastropods, and echinoids are absent. The absence of burrowing organisms and the almost complete absence of fragmented or dislocated organisms suggest an allochtonous assemblage, passively transported by low-energy mechanisms, and an anoxic environment with strong salinity variations.

\section{Materials and methods}

Fossils were found in the El Pinetell outcrop of the Alcover unit (Fig. 1). A detailed description of this locality was presented by Cartanyà (1993, 1994, 1999a, 1999b).

The analyzed individual, described as the holotype, was initially classified as an indeterminate mysidacean by Cartanyà (1991, 1993, 1994). It is an epirelief in which the fossil protrudes from the surface. The main trace suggests that this animal was settled on the bottom with the ventral surface up. As a consequence of the fossilization process, many fine details of the appendages, such as setae or spines, have been loss. A second analyzed individual (paratype) is also an epirelief settled on the bottom in ventral position, showing the dorsal part of the body.

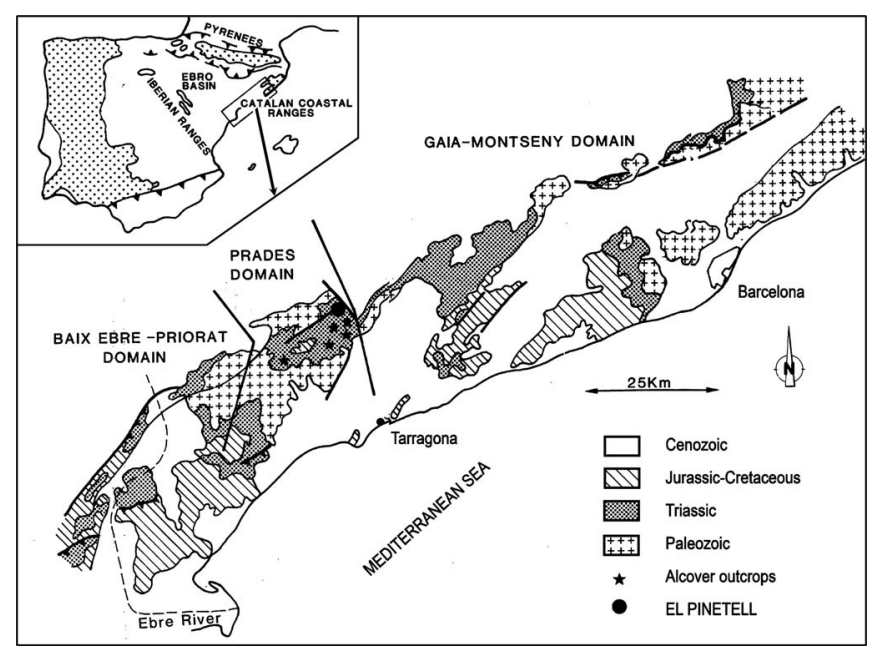

Figure 1. Locality map showing collection locality in the Alcover limestones unit of El Pinetell, in the district of Montblanc (Catalonia, Iberian Peninsula). 


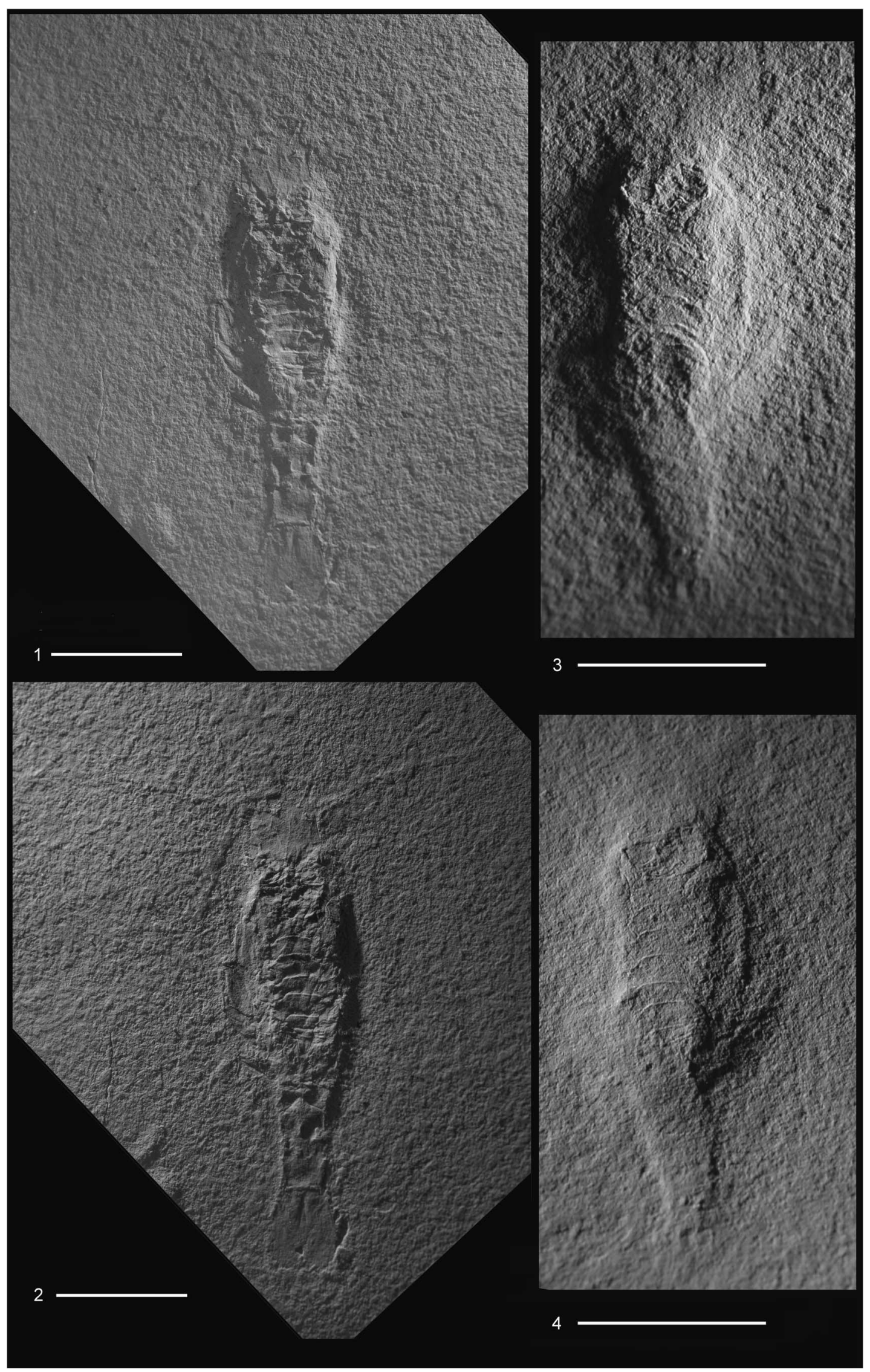

Figure 2. Aviamysis pinetellensis n. gen. n. sp.: $(\mathbf{1}, \mathbf{2})$ PI1, holotype female, photographs of the entire animal with two lateral illuminations, right side $(\mathbf{1})$ and left side $(\mathbf{2}) ;(\mathbf{3}, \mathbf{4})$ PI47, male paratype, photographs of the entire animal with two lateral illuminations, right side $(\mathbf{3})$ and left side $(\mathbf{4})$. Scale bars $=1 \mathrm{~cm}$. 


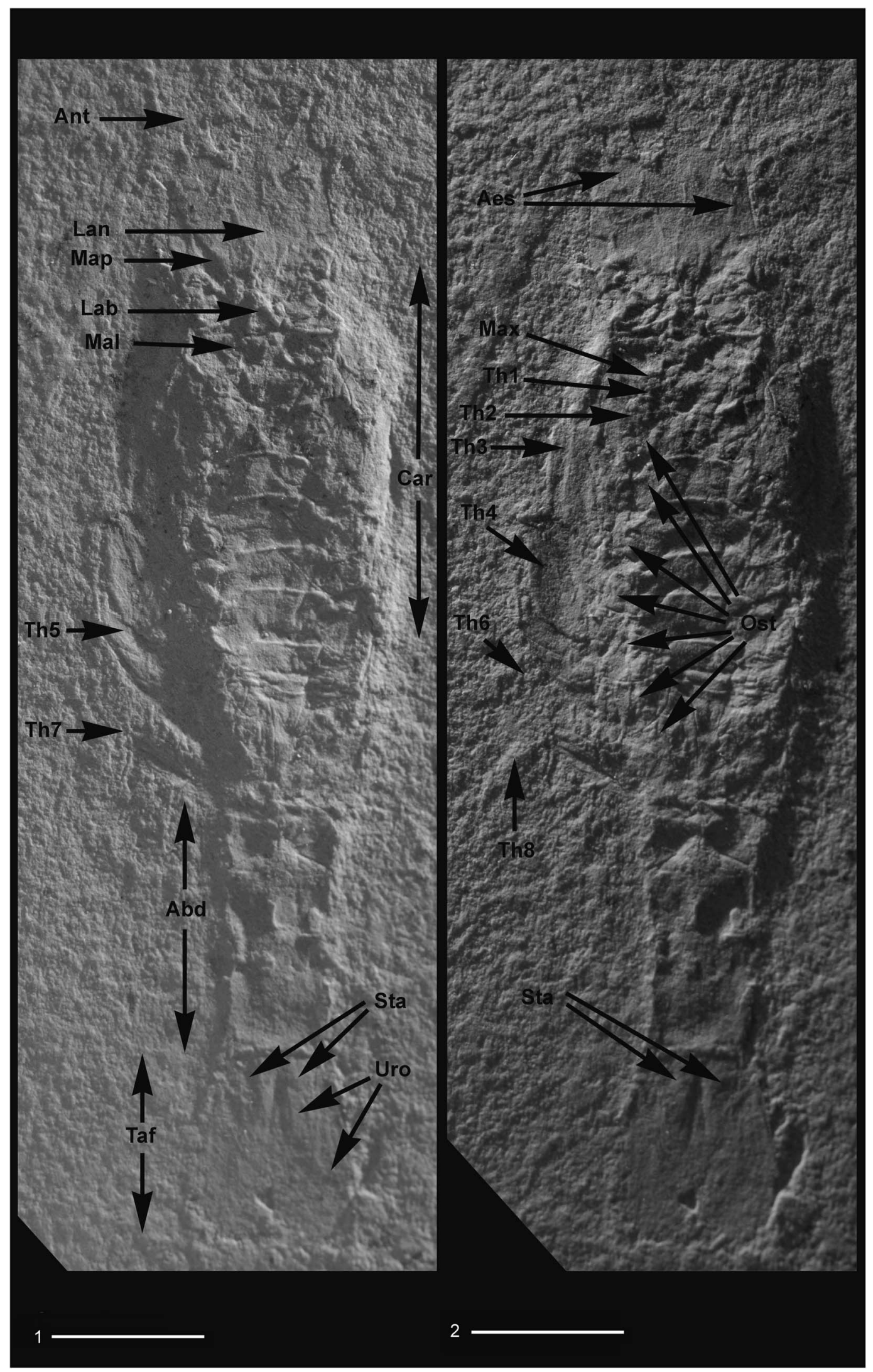

Figure 3. Aviamysis pinetellensis $\mathrm{n}$. gen. n. sp.: $(\mathbf{1}, \mathbf{2})$ PI1, holotype female, detailed photographs with two lateral illuminations, right side $(\mathbf{1})$ and left side $(\mathbf{2})$; $\mathrm{Car}=$ carapace, $\mathrm{Abd}=$ abdomen, $\mathrm{Taf}=$ tailfan, $\mathrm{Ant}=$ antennule, Aes $=$ antennal scales, $\mathrm{Lan}=$ lanceolate-shaped median ventral projection arising from front of the labrum, Lab = labrum, Map = mandible palp, Mal = maxillule, Max = maxilla, Th1 $-\mathrm{Th} 8=$ thoracopods $1-8$, Ost $=$ oostegites, Uro $=$ uropod, Sta $=$ statocysts. Scale bars $=5 \mathrm{~mm}$. 


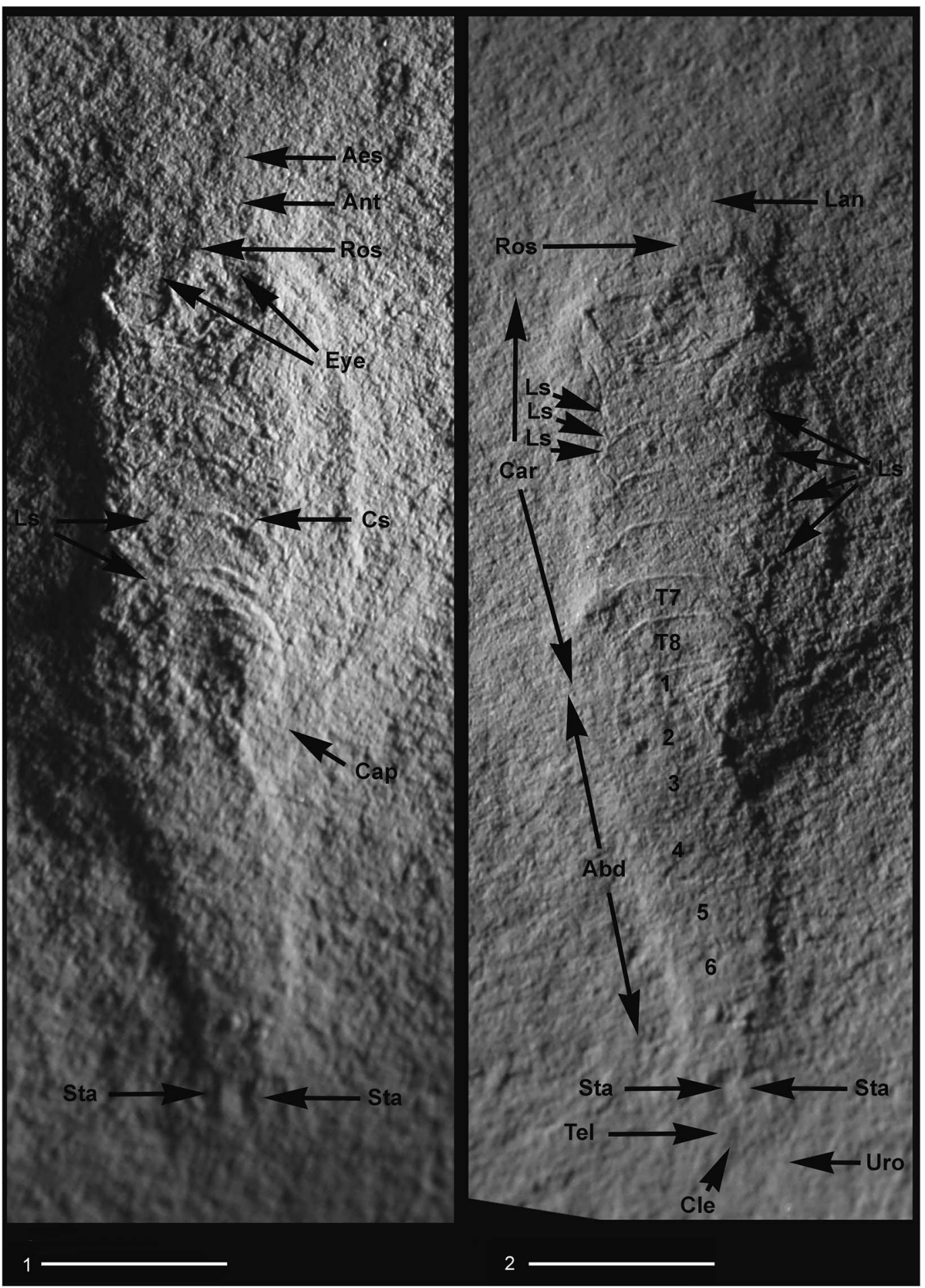

Figure 4. Aviamysis pinetellensis n. gen. n. sp.: $(\mathbf{1}, \mathbf{2})$ PI47, male paratype, detailed photographs with two lateral illuminations, right side (1) and left side $(\mathbf{2})$; Ant $=$ antennule, Aes $=$ antennal scale, Ros $=$ rostrum, Lan $=$ lanceolate-shaped median ventral projection arising from front of the labrum, Eye $=$ eyes, $\mathrm{Car}=$ carapace, $\mathrm{Cs}=$ cervical sulcus, $\mathrm{Ls}=$ spines of the carapace, $\mathrm{Cap}=$ posterolateral lobe of the carapace, $\mathrm{T} 7-\mathrm{T} 8=$ thoracic somites 7 and $8, \mathrm{Abd}=\mathrm{abdomen}$, $1-6=$ abdominal somites 1 to $6, \mathrm{Tel}=$ telson, $\mathrm{Cle}=$ telson cleft, Uro $=$ uropod, $\mathrm{Sta}=$ statocysts. Scale bars $=5 \mathrm{~mm}$.

The fossil traces are relatively thin, so they require the use of different illuminations to observe different parts of the body (Figs. 2-5). Thus, the main appendages of the right ventral side of the holotype can be recognized (these are harder to see on the left side probably due to some kind of postmortem and/or fossilization torsion), as well as other main morphological traits of both analyzed specimens. The specimen sizes were determined from the measurement of the total body length (TL: from the apex of the rostrum to the posterior end of the telson).

Nomenclature of higher crustacean taxa follows the classification proposed by Martin and Davis (2001) and higher Mysida taxa by Wittmann et al. (2014). Article 30.1.1 of the 

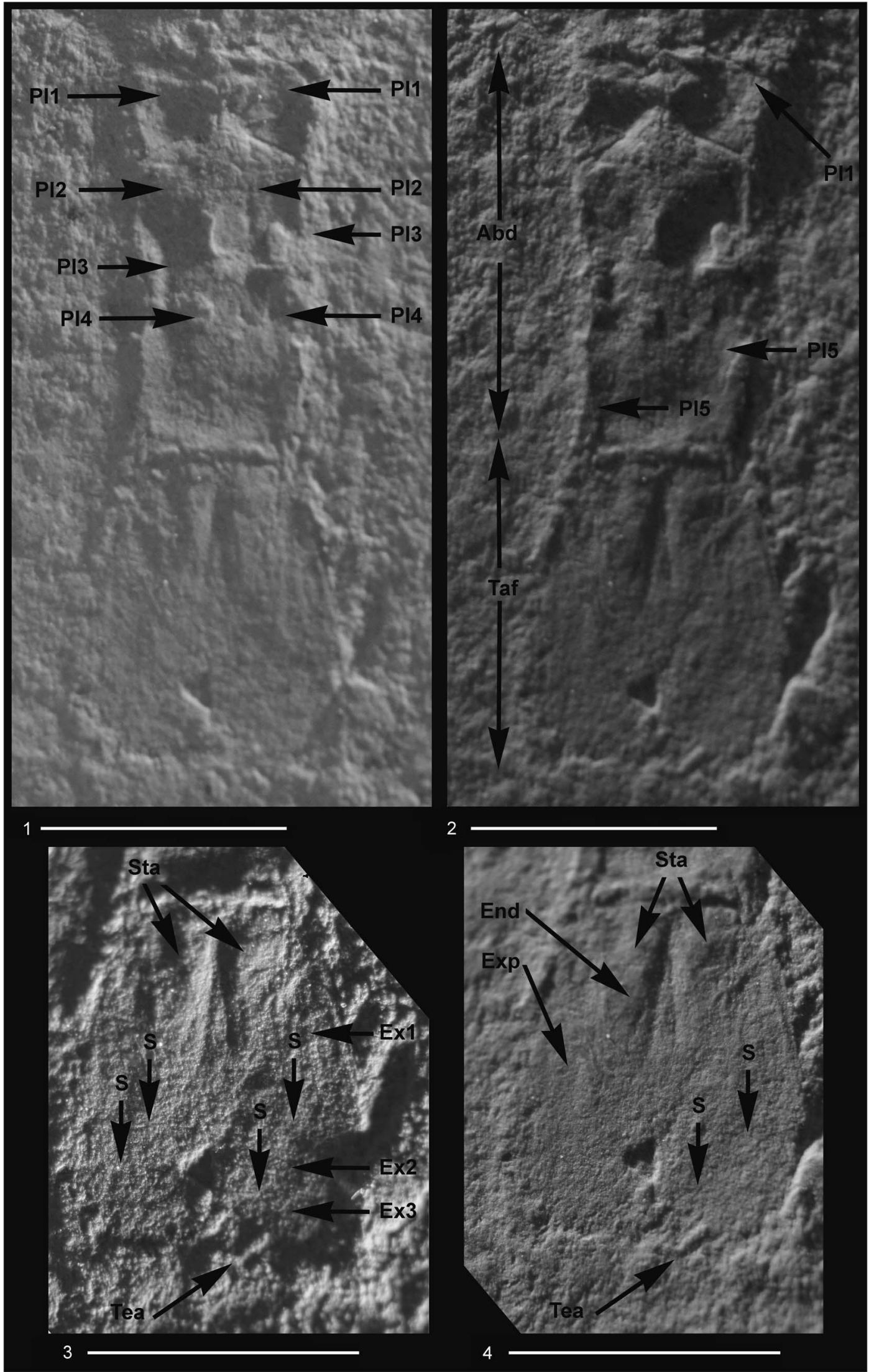

Figure 5. Aviamysis pinetellensis n. gen. n. sp.: (1-4) PI1, holotype female, detailed photographs of the abdomen and telson with two lateral illuminations, right side $(\mathbf{1}, \mathbf{3})$ and left side $(\mathbf{2}, \mathbf{4})$; Abd = abdomen, Taf = tailfan, Pl1-Pl5=pleopods 1 to 5, Exp=uropod exopod, Ex1-Ex3=uropod exopod articles 1 to 3 , $\mathrm{S}=$ sutures of the uropod exopod, End $=$ uropod endopod, $\mathrm{Sta}=$ statocysts, Tea $=$ telson apex. Scale bars $=5 \mathrm{~mm}$. 
International Code of Zoological Nomenclature (International Commission on Zoological Nomenclature, 1999) states that if the genus name is a compound word formed from two or more components, the gender is given by the final component. Thus Mysis should be treated as feminine (Holmquist, 1958), and the new genus and species is named to accord with that gender.

Repositories and institutional abbreviations.-Specimens examined in this study were collected in a field study during 1991 organized by the Centre d 'Història Natural de la Conca de Barberà (CHNCB). Type material is deposited at the Centre d'Història Natural de la Conca de Barberà (Museu Comarcal de la Conca de Barberà), Montblanc (Catalonia, Spain). Holotype catalogue number: PI1. Paratype catalogue number: PI47.

\section{Systematic paleontology}

Class Malacostraca Latreille, 1802

Subclass Eumalacostraca Grobben, 1892

Superorder Peracarida Calman, 1904

Order Mysida Boas, 1883

Family Mysidae Haworth, 1825

Subfamily Boreomysinae Holt and Tattersall, 1905

Genus Aviamysis new genus

Type species.—Aviamysis pinetellensis $\mathrm{n}$. gen. n. sp. by original designation and by monotypy.

Diagnosis.-Relatively large sized mysid distinguished within the family Mysidae through the strong, lanceolate-shaped, median, ventral projection arising from front of the labrum; antennal scale triangular, with distal transverse suture; antennal peduncle with two flagella; first thoracopod forming a short maxilliped, without exopod; seven pair of oostegites; third to fourth thoracopods with endopod elongated and robust, much longer than the other thoracopods; uropod exopod 3-articulate; uropod endopod slender, with statocyst circular and without any trace of structures; telson cleft.

Etymology.-The new genus name is given after the association with the Catalan-Latin name of the grandmother ("Avia"), due to its ancient nature, combined with the generic name Mysis to give Aviamysis. The name Aviamysis is defined as feminine.

\section{Aviamysis pinetellensis new species}

Figures 2-7

Holotype.-Holotype (PI1): one female, $38 \mathrm{~mm}$ TL. Bed of Alcover limestones unit ("Pedra d'Alcover") from El Pinetell, in the district of Montblanc; $41^{\circ} 18^{\prime} 25^{\prime \prime} \mathrm{N}, 01^{\circ} 07^{\prime} 53^{\prime \prime E}$. Paratype (PI47): one male $29 \mathrm{~mm} \mathrm{TL}$, from the same locality and sampling data as the holotype.
Diagnosis.-The same diagnostic characteristics used for the genus.

Occurrence.-Alcover laminated dolomites unit, Middle Triassic, late Ladinian, upper Muschelkalk.

Description.-Aviamysis pinetellensis n. gen. n. sp. was a relatively large mysid with an apparently robust general body form (Figs. 2-4). The reconstruction of the holotype individual (Figs. 3, 6.1), in which we interpret the presence of seven oostegites arising from the bases and coxae of the second to eighth thoracopods, as well as pleopods reduced to simple unjointed plates, indicates that the specimen was a female. Analysis of the paratype reveals characteristics of the dorsal part of the new taxon (notably the eyes and the carapace sculpture). The presence of an anteriorly produced ventral process on the distal end of the third segment of the antennule sympod of the paratype (interpreted as an appendix masculina) indicates that it was a male (Figs. 4, 6.2).

Carapace sculptured with spines, leaving the two posterior thoracic somites partially uncovered; anterior margin produced into a pointed rostrum not extending much farther than the ocular cornea; antero-lateral corners acutely produced, slightly projecting beyond anterior margin of carapace. Cervical sulcus marked, running across the dorsal surface. Four acute spines in the median cardial zone; eight smaller lateral spines on each carapace flank. Posterolateral lobes very sharp, extending to the middle second abdominal somite (Figs. 3, 4, 6.2).

Pleon shorter than the carapace in the female and subequal in length in the male, not tapering posteriorly, with the sixth somite longer than the other anterior abdominal somites (Figs. 3, 4, 5.1, 5.2, 6.2).

Eyes small, and globular, not broader than the eyestalk, laterally not extending beyond carapace limits (Figs. 4, 6.2).

Antennular sympod (Fig. 5.1,6) not extending beyond antennal scale, with three segments. First article (precoxa) longer than wide; second article (coxa) half as long as broad, third (basis) article shortest; male third article slightly broader than long, supporting an appendix masculina (Figs. 5.1, 6.2, 7.1, 7.2). The sympod supports two flagella, with the outer flagellum three to four times longer than the inner one.

Sympod of the antenna closely fused with three discernible segments: praecoxa, coxa, and basis (Figs. 3, 4.1, 6, 7.3). Antennal scale triangular in shape, three times longer than maximum width, extending beyond antennular peduncle; with apical suture. Peduncle not extending beyond scale; composed of three segments, first article twice as long as broad; second and third articles sub-equal in length, both shorter than first one. The antennal peduncle supports two flagella, with the outer flagellum three to four times longer than the inner one.

Strong, lanceolate-shaped, median ventral projection arising from front of the labrum and extending beyond halfway point to the second segment (female) or to the third segment

Figure 6. Reconstructions of the habitus of Aviamysis pinetellensis n. gen. n. sp.: (1) PI1, holotype female, (2) PI47, male paratype; Ant=antennule, Apm =appendix masculine, Anp=antennal peduncle, Ae =antennal scale, Ros = rostrum, Eye =eye, Cs=cervical sulcus, Ls $=$ spines of the carapace, $\mathrm{Cap}=$ posterolateral lobe of the carapace, T7-T8 $=$ thoracic somites $7-8$, Lan $=$ lanceolate-shaped median ventral projection arising from front of the labrum, $\mathrm{Lab}=$ labrum, Map = mandible palp, Mal=maxillule, Max = maxilla, Th1-Th8=thoracopods $1-8, \mathrm{D}=$ dactylus, $\mathrm{N}=$ nail, A1-A6=abdominal somites $1-6$, Pl1-Pl5 = pleopods 1-5, Tel $=$ telson, $\mathrm{Cle}=$ telson cleft, Exp $=$ uropod exopod, End $=$ uropod endopod, Sta $=$ statocyst. Scale bars $=5$ mm. 


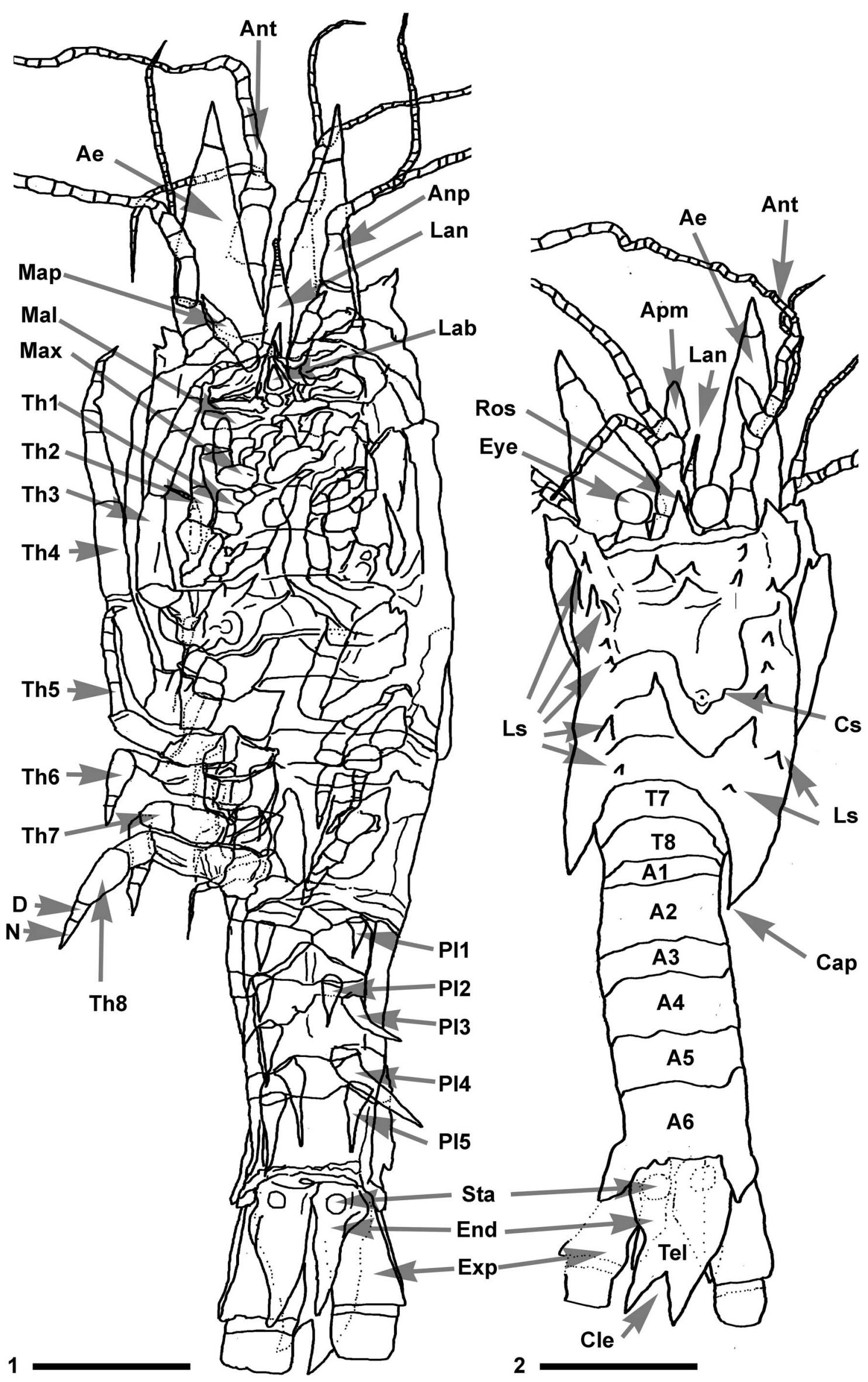


(male) of the antennular peduncle; anterior end rounded with apparent segmentation (Figs. 3.1, 6,1, 7.4).

Labrum pyriform, more or less symmetrical, half as wide as long (Fig. 3.1, 6.1, 7.4). Mandibles well developed (Figs. 3.1, 6.1, 7.4). Three-segmented palp, first article shortest; second article slightly longer than wide; third article about twice as long as broad. Third article of the right mandible with serrate outer margin. Gnathobasic processes of the left and right mandibles are not discernable; only the molar process is tenuously observed as a flat platelike structure provided with spines.

Maxillule difficult to define, without any trace of separation between the sympod and the lobes (Fig. 5.5). Maxilla exopod is seen as a plate attached to the outer side of the basis, with the outer margin markedly convex; two basal endites and endopod probably two-segmented (Figs. 3.2, 6,1, 7.5).

The first thoracopod differs considerably from the remaining thoracic appendages: modified as short maxilliped without exopod (Figs. 3.2, 6.1, 7.6). Endopod short and robust; apparently with four segments not clearly delineated, dactylus fused with nail to form a claw.

Female second to eighth thoracopods with oostegites (Fig. 3.2). Second thoracopod longer than first one, without epipodite and with exopod and oostegite (Figs. 3.2, 6.1). Endopod with preischium, ischium and merus fused, twice as long as broad; unsegmented carpopropodus three times as long as greatest width, tapering somewhat distally; dactylus short with pointed nail. Exopod shorter than endopod with basal plate and 6-segmented flagellum (Fig. 7.6).

Third to fourth thoracopods with endopod elongated and robust, much longer than the other thoracopods (Figs. 3.1, 6.1, 7.9, 7.10). Endopod preischium difficult to define, ischium and merus subequal in length; carpopropodus 4-segmented, longer than merus; dactylus with pointed distal nail. Exopod apparently much shorter than endopod.

Fifth thoracopod with endopod about one half longer than the fourth (Figs. 3.1, 6.1, 7.11). Endopod preischium difficult to define, ischium and merus subequal in length; carpopropodus 4-segmented, longer than merus; dactylus with pointed distal nail. Exopod apparently much shorter than endopod.

Sixth to eighth thoracopods quite different from the rest, with preischium and ischium more or less fused, merus short, undivided carpopropodus more or less swollen anteriorly; dactylus with pointed distal nail (Figs. 3.1, 6.1, 7.12, 7.13, 7.14). Exopods apparently much shorter than endopods. Eighth thoracopod exopod with basal plate and 5-segmented flagellum (Fig. 7.14).

Female pleopods uniramous, reduced to unsegmented lobes (Figs. 5.1, 5.2, 6.1), increasing in length from first to fourth and fifth pairs; fifth pleopod extending to posterior end of posterior abdominal somite.

Uropod endopod slender, with statocyst, not extending to telson apex, outer margin sinuous (Figs. 3-6, 8.2). Statocyst trace apparently circular with a maximum diameter of $\sim 1 \mathrm{~mm}$, without any trace of structures (Figs. 5.3, 5.4, 6, 7.15, 7.16). Uropod exopod 3-articulate, longer and broader than endopod, extending slightly beyond telson apex; distal two articles about one third length of the basal article.

Telson short, about sub-equal in length to the last abdominal somite, twice as long as broad (Figs. 3-6, 7.15, 7.16); lateral margins converging distally; apex of telson bidentate; telson cleft to about one-third of its length.

Etymology.-This species is named after "El Pinetell," the bed of Alcover limestones unit (Catalonian) in which the species was found.

Remarks. - The placement of Aviamysis n. gen. in the order Mysida family Mysidae, as defined by Wittmann et al. (2014) seems beyond doubt. This assignment is supported by the presence of eight thoracopods without branchiae and with endopods divided in a number of segments, female with seven pair of oostegites, female with five rudimentary pleopods, and the presence of statocysts on the endopod of uropods. Its taxonomic situation among the diverse subfamilies included in the Family, however, is relatively ambiguous.

The family Mysidae is divided at present into ten subfamilies (Meland et al., 2015), of which, Aviamysis has a clear affinity to the subfamily Boreomysinae. Boreomysinae are characterized by the following: a smooth outer margin on the antennal scale ending in non-articulate spine; seven pairs of oostegites; endopods of the third to the eighth thoracopods with carpus distinct and propodus usually divided into two or three subsegments; pleomeres without projecting pleural plates; females with pleopods reduced to unsegmented rods; exopod of uropods divided by a rudimentary, transverse articulation; statocyst containing a small, non-mineralized statolith; and telson with apical cleft (Tattersall and Tattersall, 1951; Wittman et al., 2014). Two extant genera are included in this subfamily: Boreomysis Sars, 1869, and Birsteiniamysis Tchindonova, 1981.

In accordance with this definition of the subfamily, the placement of Aviamysis in the Boreomysinae seems reasonable. In particular, different morphological characters traditionally regarded as plesiomorphic features between the order Mysida, as discussed by Schlacher et al. (1992), are present on the subfamily Boreomysinae (e.g., subdivided exopod of uropods and seven pairs of oostegites). The remaining Mysidae taxa usually have two or three pairs of oostegites (Wittmann et al., 2014).

An additional shared character state in the basal taxa Petalophthalmidae, Boreomysinae, and Rhopalophthalminae (and also in the more derived Siriellinae) is the presence of a suture in the exopod of uropod. With reference to molecular phylogeny (Meland and Willassen, 2007), the divided exopod gains support as an ancestral state in Mysida evolution (Meland et al., 2015).

Figure 7. Detailed reconstructions of the main appendages of Aviamysis pinetellensis n. gen. n. sp.: (1, 3-15) PI1, holotype female, (2, 16) PI47, male paratype. (1) Female antennule; (2) male antennule; (3) antenna; (4) labrum, mandibles and the lanceolate-shaped median ventral projection arising from front of the labrum; (5) maxillule; (6) maxilla; (7) 1st thoracopod; (8) 2nd thoracopod; (9) 3rd thoracopod; (10) 4th thoracopod; (11) 5th thoracopod; (12) 6th thoracopod; (13) 7 th thoracopod; (14) 8th thoracopod; (15) female telson and uropods in ventral view; (16) male telson and uropods in dorsal view. Scale bar $1-14=0.5$ mm; scale bar $15,16=0.2 \mathrm{~mm}$. 


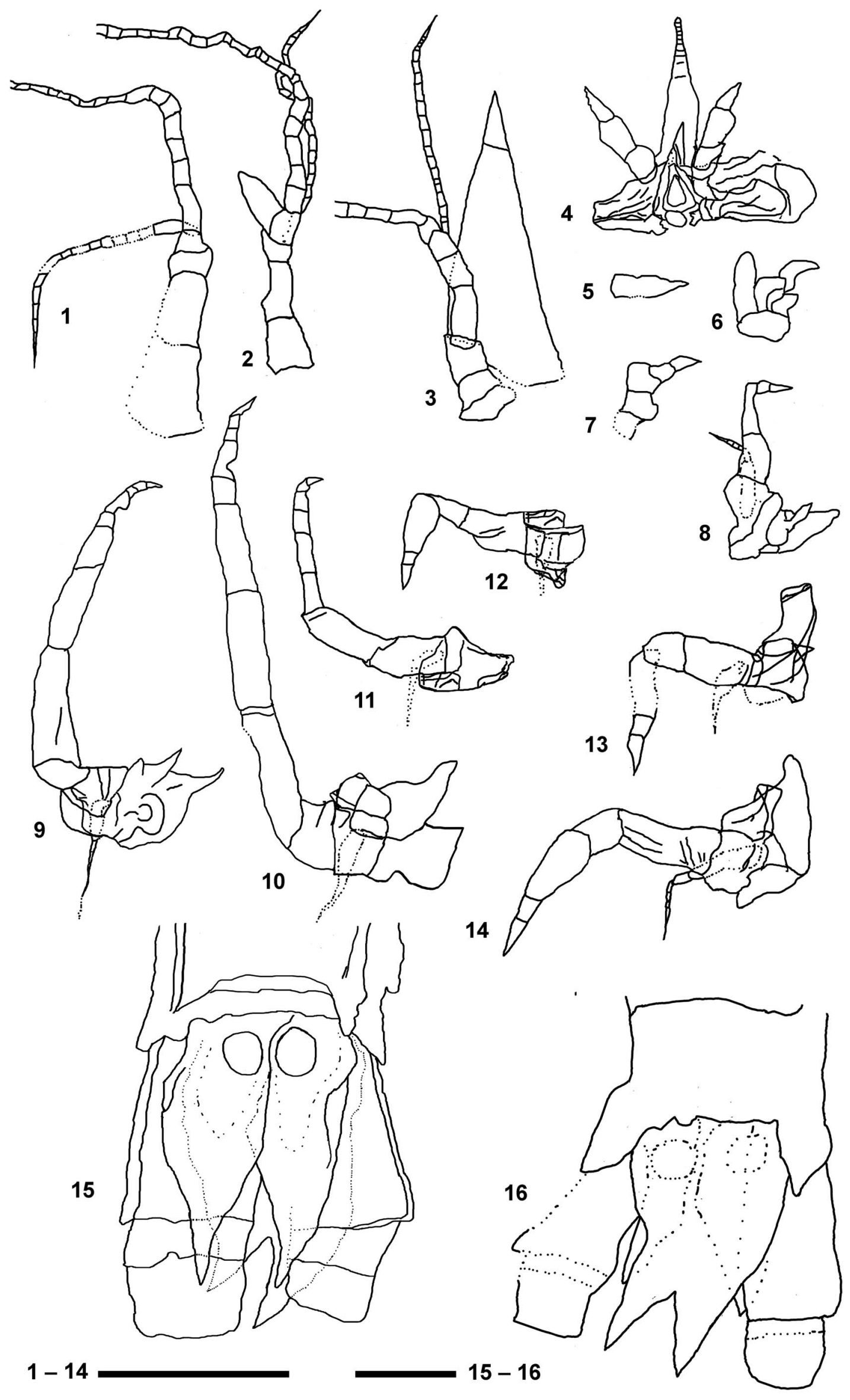


The statocyst in Aviamysis n. gen. is apparently circular and without any trace of internal structure, such as statolith. Strong support for an ancestral status of Boreomysinae is also seen in the non-mineralized (organic) composition of the uropodal statoliths, a trait also found in the basal taxon Rhopalophthalminae. In both subfamilies, the nearly exclusively non-crystalline (organic) structure of the statoliths is plesiomorphic compares with the more complex mineralized statoliths found in all other subfamilies (Ariani et al., 1993; Wittmann et al., 1993).

It is noteworthy several features of Aviamysis, such as the presence of an antennal flagella, the strong lanceolate-shaped median ventral projection arising ventrally from front of the labrum and extending beyond it, similar to those of extant species such as Paramblyops brevirostris Tattersall, 1955 or Schistomysis assimilis (Sars, 1877), and the shape of the uropod exopod and the configuration of the thoracopods. Thus, assignment of Aviamysis to the subfamily Boreomysinae remains tentative.

A morphological peculiarity of Aviamysis concerns the shape of the antenna. This appendix includes a sympod with three discernible segments (praecoxa, coxa, and basis), an antennal scale and a peduncle composed of three segments that supports two flagella. This structure can be considered as unique within the order Mysida because, in general, the antennal endopod takes on the form of a multi-segmented flagellum (Tattersall and Tattersall, 1951; Meland et al., 2015). A second peculiarity is derived from the 3-segmented uropodal exopod in Aviamysis: in Mysida, the uropodal exopod is divided by no more than two distal or proximal articulations. Finally, the configuration of thoracopods in Aviamysis differs from those seen in living Boreomysinae (Tattersall and Tattersall, 1951). In Aviamysis, the thoracopods are grouped in at least two different shape groups (third to fourth thoracopods with endopod elongated and robust, sixth to eighth with shorter endopods and undivided carpopropodus). By comparison, in Boreomysinae the endopods of the third-eighth thoracopods are all similar in shape, with the carpus distinct and propodus usually divided into two or three subsegments.

The formalization of a new subfamily based on the description of only two fossil individuals seems very hazardous, so we included it (with reservation) in the Boreomysinae. However, given the scale of time elapsed between the age of Aviamysis and the first fossils of previously known Mysida $(\sim 70 \mathrm{Myr})$, it is not impossible that this taxon will someday define a new subfamily. To do this, however, discovery and descriptions of new Mysida fossils from the Triassic will be necessary.

\section{Discussion}

Taylor et al. (1998) provided a large-scale phylogenetic analysis including recent "mysidacean" and lophogastrid taxa plus fossil pygocephalomorphs. True fossils of the order Mysida have been dated as far back as Middle Jurassic time (Callovian, 163-166 Myr). These animals were well developed, very similar in appearance to the mysids of today, which led Secretan and Riou (1986) to suggest that the evolutionary stage reached by the Jurassic has not appreciably changed in the intervening time period. As suggested by Taylor et al. (2001), the Mysida origin was sometime before the Jurassic, although the question of where and when cannot yet be answered. The description of the fossil specimens of El Pinetell presented in this study strengthens the evidence for the suggestion of Taylor et al. (2001), as well as greatly extends time of the origin of this crustacean order. Moreover, the general appearance of Aviamysis n. gen. provides greater morphological diversity to the first fossil forms and, consequently, to the evolutionary history of the order Mysida.

The mode of life of Aviamysis pinetellensis n. gen. n. sp. in the Middle Triassic marine environment of the Western Tethys is an open question. Marine conditions prevailing in the Iberian region during the Triassic, especially during the whole Ladinian, included a wide diversity of coastal and depositional environments (shores, lagoons, tidal flats, reefs, etc.). Assemblage information from the Alcover unit suggests that this Triassic mysid lived in a marine shallow environment or lagoonal basin within an extended reef complex.

Some features of Aviamysis pinetellensis n. gen. n. sp. suggest that this mysid could have had an epibenthic lifestyle: (1) the general body form was apparently robust; (2) the shape of the thoracopod exopods, apparently much shorter than the endopods; and (3) the short abdomen. The relatively robust thoracopod endopods also suggest a good capacity for benthic locomotion.

Schram (1974) proposed that the radiation of the Peracarida took place in the Permo-Triassic, which is the period when the first recognisable peracarid fossils appeared (Schram, 1986). In his view, the dominant Palaeozoic peracarids were the Pygocephalomorpha, which were epibenthic. At the end of the Permian, primitive peracarids occupied refugia or went extinct and were replaced by advanced peracarids adapted to benthic strategies (Poore, 2005). In this sense, comparing the zoogeographic distribution of extant genera with that of the fossil forms, Udrescu (1984) also hypothesized that primitive Lophogastrida were littoral-benthic forms. In contrast with the more recent interpretations of the Triassic Lophogastrida pelagic lifestyle (Feldmann et al., 2015, 2017), data provided by the new fossil taxon described here seem to corroborate that the first Triassic representatives of the order Mysida probably had an epibenthic lifestyle and lived in a coastal benthic environment, from which they were diversified to colonize a broad range of aquatic ecosystems on Earth.

\section{Acknowledgments}

We wish to express our gratitude to F. Aguilar for providing us with the nice photographs of the holotype. Special thanks to the referees (C.E. Schweitzer and an anonymous reviewer) for improving the manuscript.

\section{References}

Ariani, A.P., Wittmann, K.J., and Franco, E., 1993, A comparative study of static bodies in mysid crustaceans: evolutionary implications of crystallographic characteristics: The Biological Bulletin, v. 185, p. 393-404.

Beltan, L., Calzada, S., Via, L., and Villalta, F., 1989, On Ladinian biotas from northeastern Spain: Abstracts 28th International Geological Congress, Washington D.C., v. 1, p. 121-123. 
Boas, J.E.V., 1883, Studien über die Verwandtschaftsbeziehungen der Malakostraken: Morphologisches Jahrbuch, v. 8, p. 485-579.

Broili, F., 1917, Eine neue Crustaceen- (Mysidaceen-) Form aus dem lithographischen Schiefer des oberen Jura von Franken: Zentralblatt für Mineralogie, Geologie, und Paläontologie, v. 19, p. 426-429.

Calman, W.T., 1904, On the classification of the Crustacea Malacostraca: The Annals and Magazine of Natural History, ser. 7, v. 13, p. 144-158.

Calvet, F., and Tucker, M.E., 1995, Geological setting Alcover laminated dolomites, in Martínez-Delclòs, X., ed., Montsec and Mont-ral-Alcover, two Konservat-Lagerstätten. Catalonia, Spain: International Symposium on Lithographic Limestones Pre-Symposium Field-Trip, Lleida, p. 73-80.

Calvet, F., March, M., and Pedrosa, A., 1987, Estratigrafía, sedimentología y diagénesis del Muschelkalk superior de los Catalánides: Cuadernos Geología Ibérica, v. 11, p. 171-197.

Carrasco, J.F., 2012, A new ichnospecies of Asteriacites from the Triassic of Tarragona (Spain): Batalleria, v. 16, p. 12-15.

Cartanyà, J., 1991, Nous Crustacis al registre fossil de la Conca de Barberà: Reboll, v. 2, p. 27-30.

Cartanyà, J., 1993, El Pinetell, un nou jaciment paleontològic de la "pedra d'Alcover" a la Conca de Barberà: Reboll, v. 6, p. 33-42.

Cartanyà, J., 1994, Noves aportacions paleontologiques al Muschelkalk superior de les muntanyes de Prades: el cas del Pinetell: Quaderns de Vilaniu, v. 25, p. 67-93.

Cartanyà, J., 1999a, Peixos actinopterigis del triàsic mitjà de la pedra d'Alcover: Quaderns de Vilaniu, v. 35, p. 55-87.

Cartanyà, J., 1999b, An overview of the Middle Triassic actinopterygians from Alcover, Mont-ral and El Pinetell (Catalonia, Spain), in Arratia, G., and Schultze, H.-P., eds., Mesozoic Fishes 2-Systematics and Fossil Record: München, Verlag Dr. Pfeil, p. 535-551.

De Angeli, A., and Rossi, A., 2006, Crostacei ologocenici di Peralolo (Vicenza-Italia settentrionale), con la descrizione di una nuova specie di Mysida e di Isopoda: Società Veneziana di Scienze Naturali-Lavori, v. 31, p. 85-93.

Erwin, D.H., 1996, Recoveries and radiations: gastropods after the PermoTriassic mass-extinction, in Hart, M.B., ed., Biotic Recovery from Mass-Extinction Events: Geological Society Special Publications, v. 102, p. $223-229$.

Escudero-Mozo, M.J., Márquez-Aliaga, A., Goy, A., Martín-Chivelet, J., LópezGómez, J., Márquez, L., Arche, A., Plasencia, P., Pla, C., Marzo, M., and Sánchez-Fernández, D., 2015, Middle Triassic carbonate platforms in eastern Iberia: evolution of their fauna and palaeogeographic significance in the western Tethys: Palaeogeography, Palaeoclimatology, Palaeoecology, v. 417 , p. 236-260.

Esteban, M., Calzada, S., and Vía, L., 1977, Ambiente deposicional de los yacimientos fosilíferos del Muschelkalk superior de Alcover, Mont-Ral: Cuadernos Geología Ibérica, v. 4, p. 189-200.

Feldmann, R.M., Schweitzer, C.E., Hu, S., Huang, J., Zhou, C., Zhang, Q., Wen, W., Xie, T., and Maguire, E., 2015, Spatial distribution of Crustacea and associated organisms in the Luoping Biota (Anisian, Middle Triassic), Yunnan Province, China: evidence of periodic mass kills: Journal of Paleontology, v. 89, p. 1022-1037.

Feldmann, R.M., Schweitzer, C.E., Hu, S., Huang, J., Zhou, C., Zhang, Q., Wen, W., Xie, T., F.R. Schram, F.R., and Wade, T.J., 2017, Earliest occurrence of lophogastrid mysidacean arthropods (Crustacea, Eucopiidae) from the Anisian Luoping Biota, Yunnan Province, China: Journal of Paleontology, v. 91 , p. $100-115$.

Fortuny, J., Bolet, A., Sellés, A.G., Cartanyà, J., and Galobart, A., 2011, New insights on the Permian and Triassic vertebrates from the Iberian Peninsula with emphasis on the Pyrenean and Catalonian basins: Journal of Iberian Geology, v. 37, p. 65-86.

Grobben, C., 1892, Zur Kenntniss des Stammbaumes und des Systems der Crustaceen. Sitzungsberichte der Kaiserlichen Akademie der Wissenschaften: Mathematisch-Naturwissenschaftliche Classe, Abt. 1, v. 101 , p. $237-274$.

Haworth, A.H., 1825, A new binary arrangament of the brachyurous Crustacea: Philosophical Magazine Journal, v. 65, p. 105-106, 183-184.

Holmquist, C., 1958, Proposed use of the plenary powers to validate a neotype for the nominal species "Cancer oculatus" Fabricius (O.) 1780, to designate the species so named to be the type species of the genus "Mysis" Latreille, (1802-1803) (Class Crustacea, Order Mysidacea) and matters incidental thereto: Bulletin of Zoological Nomenclature, v. 16, p. 51-61.

Holt, E.W.L., and Tattersall, W.M., 1905, Schizopodous Crustacea from the north-east Atlantic slope: Report on the Sea and Inland Fisheries of Ireland, 1902-1903: Dublin, Alexander Thom \& Co., Pt. 2, App. 4, p. $99-152$

International Commission on Zoological Nomenclature 1999, International Code of Zoological Nomenclature, 4th Edition: London, International Trust for Zoological Nomenclature, $306 \mathrm{p}$.
Ionesi, V., and Pascariu, F., 2011, The relationship between the Sarmatian and Quaternary formations from the Păcurari area (Iaşi, Romania): Analele Stiintifice ale Universitatii "Al. I. Cuza" din Iasi Seria Geologie, v. 57 , p. $5-14$.

Latreille, P.A., 1802, Histoire Naturelle, Générale et Particulière des Crustacés et des Insectes: Ouvrage Faisant Suite aux Oeuvres de Leclerc de Buffon, et Partie du Cours Complet d'Histoire Naturelle Rédigé par C.S. Sonnini: Paris, F. Dufart, v. 3, 467 p.

López-Gómez, J., Arche, A., and Pérez-López, A., 2002, Permian and Triassic, in Gibbons, W., and Moreno, T., eds., The Geology of Spain: London, Geological Society Publishing House, p. 185-212.

Lucas, S.G., 2010, The Triassic timescale: an introduction: Geological Society, London, Special Publications, v. 334, p. 1-16.

Márquez-Aliaga, A., 2010, The Triassic of the Iberian Micro-Plate: the Early Mesozoic Pre-Jurassic Tethys Hinge: Earth Science Frontiers, v. 17, p. 366-367.

Martin, J.W., and Davis, G.E., 2001, An updated classification of the Recent Crustacea: Natural History Museum of Los Angeles County, Science Series, v. 39 , p. $1-124$.

Meland, K., and Willassen, E., 2007, The disunity of "Mysidacea" (Crustacea): Molecular Phylogenetics and Evolution, v. 44, p. 1083-1104.

Meland, K., Mees, J., Porter, M., and Wittmann, K.J., 2015, Taxonomic Review of the Orders Mysida and Stygiomysida (Crustacea, Peracarida): PLoS ONE, v. 10, e0124656 doi: 10.1371/journal.pone.0124656.

Münster, G., 1839, Über die fossielen langschwänzigen Krebse in Kalkschiefern von Bayern: Beiträge Petrefakten-kunde, v. 2, p. 78-81.

Pesce, G.L., and Iliffe, T.M., 2002, New records of cave-dwelling mysids from the Bahamas and Mexico with description of Palaumysis bahamensis $\mathrm{n}$. $\mathrm{sp}$. (Crustacea: Mysidacea): Journal of Natural History, v. 36, p. 265-278.

Poore, G.C.V., 2005, Peracarida: monophyly? relationships and evolutionary success: Nauplius, v. 13, p. 1-27.

Rabadà, D., 1990, Crustáceos decápodos de Las Hoyas (Cuenca) y del Montsec de Rúbies (Lleida). Calizas litograficas del Cretácico inferior de España: Acta Geológica Hispánica, v. 25, p. 299-311.

Sanz, J.L., Wenz, S., Yebenes, A., Estes, R., Martinez-Delclos, X., JimenezFuentes, E., Diéguez, C., Buscalioni, A.D., Barbadillo, L.J., and Via, L., 1988, An early Cretaceous faunal and floral continental assemblage: las Hoyas fossil site (Cuenca, Spain): Geobios, v. 21, p. 611-635.

Sars, G.O., 1869, VII. Undersøgelser over Christianiafjordens Dybvandsfauna: Nyt Magazin for Naturvidenskaberne, v. 16, p. 305-362.

Sars, G.O., 1877, Nye Bidrag til Kundskaben om Middelhavets Invertebratfauna I. Middelhavets Mysider: Archiv for Mathematik og Naturvidenskab, v. 2, p. $10-119$.

Schlacher, T.A., Wittmann, K.J., and Ariani, A.P., 1992, Comparative morphology and actuopalaeontology of mysid statoliths (Crustacea, Mysidacea): Zoomorphology, v. 112, p. 67-79.

Schram, F.R., 1974, Paleozoic Peracarida of North America: Fieldiana Geology, v. 33 , p. $95-124$

Schram, F.R., 1986, Crustacea: New York, Oxford University Press, 606 p.

Secretan, S., and Riou, B., 1986, Les Mysidacés (Crustacea, Peracarida) du Callovien de la Voulte-sur-Rhône: Annales de Paléontologie (VertébrésInvertébrés), v. 72, p. 295-323.

Sepkopski, J.J. Jr., 1984, A kinetic model of Phanerozoic taxonomic diversity. III. Post Paleozoic families and mass extinction: Paleobiology, v. 10, p. 246-267.

Steurbaut, E., 1989, The first fossil mysid statolith (Crustacea) to be described from Western Europe: Micropaleontology, v. 35, p. 188-190.

Tattersall, O.S., 1955, Mysidacea: Discovery Reports, v. 28, p. 1-190.

Tattersall, W.M., and Tattersall, O.S., 1951, The British Mysidacea: London, Ray Society, $460 \mathrm{p}$.

Taylor, R.D., Schram, F.R., and Shen, Y.-B., 2001, A new upper middle Triassic shrimp (Crustacea: Lophogastrida) from Guizhou, China, with discussion regarding other fossil "mysidaceans": Journal of Paleontology, v. 75, p. 310-318.

Taylor, R.S., Shen, Y., and Schram, F.R., 1998, New pygocephalomorph crustaceans from the Permian of China and their phylogenetic relationships: Palaeontology, v. 41, p. 815-834.

Tchindonova, Y.G., 1981, New data on systematic position of some deep-sea mysids (Mysidacea, Crustacea) and their distribution in the world ocean: Proceedings of the XIV Pacific Science Congress, v. 14, p. 24-33.

Tucker, M., and Marshall, J., 2004, Diagenesis and geochemistry of Upper Muschelkalk (Triassic) buildups and associated facies in Catalonia (NE Spain): a paper dedicated to Francesc Calvet: Geologica Acta, v. 2, p. $257-269$

Udrescu, A., 1984, Transpecific evolution (family level) within Lophogastrida. A new family - Gnathophausiidae (Lophogastrida, Mysidacea): Travaux du Muséum National d'Histoire Naturelle "Grigore Antipa", v. 25, p. 59-77.

Via, L., and Villalta, J.F., 1975, Restos de crustáceos decápodos en el Triásico de Mont-ral-Alcover (Tarragona): Boletín Geológico Minero Madrid, v. 86, p. 485-497. 
Via, L., Villalta, J.F., and Esteban-Cerdá, M., 1977, Paleontología y paleoecología de los yacimientos fosilíferos del Muschelkalk superior entre Alcover y Mont-ral (Montañas de Prades, Provincia de Tarragona): Cuadernos de Geología Ibérica, v. 4, p. 247-256.

Villalta, J.F., and Via, L., 1966, Un nuevo Celacántido en el Triásico español: Acta Geológica Hispánica, v. 1, p. 21-23.

Voicu, G.H., 1974, Identification des mysidés fossiles dans les dépots du Miocene Superieur de la Paratethys Centrale et Orientale et leur importance paléontologique, stratigraphique et paléogéographique: Geologicky Zbornik-Geologica Carpathica, v. 25, p. 231-239.

Voicu, G.H., 1981, Upper Miocene and recent mysid statoliths in Central and Eastern Paratethys: Micropaleontology, v. 27, p. 227-247.
Wittmann, K.J., Schlacher, T.A., and Ariani, A.P., 1993, Structure of Recent and fossil mysid statoliths (Crustacea, Mysidacea): Journal of Morphology, v. 215 , p. $31-49$.

Wittmann, K.J., Ariani, A.P., and Lagardère, J.-P., 2014, Chapter 54: Order Lophogastrida Boas, 1883, Stygiomysida Tchindonova, 1981, and Mysida Boas, 1883 (also known collectively as Mysidacea), in von Vaupe Klein, J.C., Charmantier-Daures, M., and Schram, F.R., eds., Treatise on Zoology-Anatomy, Taxonomy, Biology. The Crustacea. Revised and updated, as well as extended from the Traité de Zoologie, v. 4, pt. B: Leiden/ Boston, Brill, p. 189-396.

Accepted 4 April 2017 